\title{
Review of the plants with anti-inflammatory activity studied in Brazil
}

\author{
Heloina de S. Falcão, Igara O. Lima, Vanda L. dos Santos, Harlan de F. Dantas, Margareth \\ de F.F.M. Diniz, José M. Barbosa-Filho, Leônia M. Batista, ${ }^{*}$
}

Laboratório de Tecnologia Farmacêutica “Delby Fernandes de Medeiros”, Universidade Federal da Paraíba, Caixa Postal 5009, 58051-970, João Pessoa, PB, Brazil

\begin{abstract}
The inflammatory reaction is a response of the organism against an injury and it involves the action of complex events and mediators through of the blood vessels. The present work is a literature survey of the extracts of plants with anti-inflammatory activity studied in Brazil. The review refers to 75 plants with their families, parts used, type of extract used, bioassay models and their activity.
\end{abstract}

Keywords: Anti-inflammatory activity, medicinal plants, natural products, review.

\section{INTRODUCTION}

Inflammation or flogose is a reaction of the tissue blood vessels against aggressor agent characterized by access of liquids and of cells to interstice (Lope et al., 1987). The inflammatory reaction is characterized by blush, heat, tumor, pain and lost function (Dassoler et al., 2004).

There are many causes for the inflammations, but the mechanisms are common to all. The inflammatory agent acts in the cell membranes inducing the activation of phospholipase $\mathrm{A}_{2}$ and consequently, liberates arachidonic acid and metabolites. According to Dassoler et al. (2004) the inflammatory mediators such as cytokine, histamine, serotonin, leukotrienes and prostaglandin increase the vascular permeability to all on the migration leukocytes cells to act on the site of inflamed tissue. Any interruption of this sequence of events results in the reduction of the liberation of the mediators causing the microcirculation to come back to normal hemodynamic state (Lope et al., 1987).

Although, there is a defense mechanism, the complex events and mediators involved in the inflammatory reaction can induce, maintain or aggravate many diseases (Sosa et al., 2002). The non steroidal antiinflammatory drugs (NSAIDs) are one of the categories of drugs most frequently used by population. However, these drugs cause adverse gastric reactions, inhibit renal function, reduce the efficacy of the diuretics and retard the angiotensin converting enzyme inhibitors (Gaddi et al., 2004).

The use of anti-inflammatory agents is helpful in the therapeutic treatment of the pathologies. The medicinal plants are widely used in folk medicine of many countries to treat different inflammatory conditions and, in particular, skin inflammations. However, for many of the plants in use, the real efficacy and the relevant active principles are unknown. Consequently, experimental studies aimed at demonstrating the pharmacological properties of these plants and identifying the relevant active principles are needed (Sosa et al., 2002).

In the course of our continuing search for bioactive natural products from plants, we recently published some reviews on crude plant extracts and plantderived compounds with potential antitumor activity against mammary (Moura et al., 2001), uterine cervical (Moura et al., 2002) and ovarian neoplasia (Silva et al., 2003), antileishmanial activity (Rocha et al., 2005), HMG CoA reductase inhibitors (Gonçalves et al., 2000), central analgesic activity (Almeida et al., 2001), prevention of the osteoporosis (Pereira et al., 2002) and for the treatment of Parkinson's disease (Morais, 2003). In the present work we have reviewed the literature related with plants of the Brazil with anti-inflammatory activity.

\section{MATERIAL AND METHODS}

The anti-inflammatory activity of the plants was searched through the data bank of the University of Illinois in Chicago, the NAPRALERT (Acronym for Natural Products ALERT). The data were updated in December 2004, using anti-inflammatory plants as legend. The plant extracts studied in Brazil were selected for this work and the references found in the search were later consulted for details on the models or mechanisms.

\section{RESULTS AND DISCUSSION}

It was possible in this review to list seventy five species of medicinal plants with anti-inflammatory activity. Those species are distributed in thirty six families of which the following stood out: Asteraceae, Fabaceae, Euphorbiaceae and Apocynaceae with 10, 10, 5 and 4 species, respectively, studied so far. 
The effectiveness of the plant extracts was dependent on the type of extract used, the model of ulcer induction and the organism tested. Thus, it was possible to classify the extracts as strongly active, active, weakly active, inactive and equivocal.

\section{Anti-inflammatory activity of crude plant extracts}

Plants of the genus Bouchea are popularly known as "gervão". The leaves of Bouchea fluminensis contain iridoid and steroid glycosides that are present in the form of crude triterpene mixture having antiinflammatory property. The purified fraction was found to contain ursolic, oleanolic and micromeric acids (Costa et al., 2003).

According to Costa et al. (2003) the antiinflammatory activity of oleanolic and ursolic acid inhibiting the edema induced by carrageenin or serotonin have been attributed to various mechanisms which include: inhibition of lipoxygenase and cyclo-oxygenase, inhibition of elastase and inhibition of complementary system (possibly through the inhibition on C3-convertase of the classical complementary pathway).

Gochnatia polymorpha (Less.) Cabr. is distributed in Southern Brazil and it is known in popular medicine as "cambara". The leaves of this plant have been found to contain sesquiterpenes and lactone derivatives. From G. polymorpha leaves were obtained various fractions, and the EtOAc fraction showed significant antiedematogenic activity with a dose level of $150 \mathrm{mg} /$ $\mathrm{kg}$ on carrageenin model in rats when this activity was compared to a control group, the amino acid 4-hydroxy$\mathrm{N}$-methyl-proline, that showed significant inhibition of edema with a dose level $200 \mathrm{mg} / \mathrm{kg}$ (Moreira et al., 2000).

Hyptis pectinata (L.) Poit (Lamiaceae) is popularly known in Brazil as "sambacaita" or "canudinho". The essential oil of the leaves of this species contains $95.8 \%$ of monoterpenes and the aqueous extract of $H$. pectinata leaves was tested in rat for the observation of antiedematogenic effects using the carrageenin and arachidonic acid induced paw edema model. The extract administered orally at the dose of $600 \mathrm{mg} / \mathrm{kg}$ exhibited a significant antiedematogenic activity (34.1\% inhibition). The doses of 200 and $400 \mathrm{mg} / \mathrm{kg}$ did not show any significant differences on the first model. In another set of experiment, the intraperitoneal administration of the extract at the dose level of $300 \mathrm{mg} / \mathrm{kg}$ inhibited the ratpaw edema by $33.8 \%$. The results show that the aqueous extract of $H$. pectinata acts on both the cyclooxygenase and lipoxygenase pathways (Bispo et al., 2001).

Pterodon pubescens is popularly called "sucupira" in Brazil. Sabino et al. (1999) studied the hydroalcoholic extract of $P$. pubescens seeds in an arthritis model for preventive and therapeutic antiarthritic treatment. The preventive treatment significantly reduced the arthritic index and the arthritis incidence induced by collagen. Therefore, that study results, provide a preliminary scientific foundation for the use of $P$. pubescens infusions in popular medicine for the treatment of rheumatoid arthritis.

Franzotti et al. (2000) studied Sida cordifolia L. (Malvaceae) which is popularly known in Brazil as "malva-branca" or "malva-branca-sedosa". The aqueous extract (AE) of S. cordifolia leaves was studied to assess the anti-inflammatory properties using the carrageenin and arachidonic acid induced rat paw edema model. The administration of a dose level of $400 \mathrm{mg} / \mathrm{kg}$ of the extract of $S$. cordifolia showed $28.31 \%$ reduction in edema, whereas the dose level of $200 \mathrm{mg} / \mathrm{kg}$ was ineffective in reducing edema, and the dose of $800 \mathrm{mg} / \mathrm{kg}$ inhibited by $7.55 \%$ in the model of carrageenin-induced edema. This model involves three distinct phases: (1) the release of histamine and serotonin, (2) the release of kinins and (3) the release of prostaglandins. The arachidonic acid model is highly sensitive to inhibitors of the lipoxygenase pathway and is resistant to selective cyclooxygenase inhibitors. Thus, the dose $200 \mathrm{mg} / \mathrm{kg}$ was ineffective as antiedematogenic. According to the results obtained from the inflammation models used in the present study, $S$. cordifolia seems not to interfere with the lipooxygenase pathway but rather with the cyclooxygenase pathway (prostaglandin biosynthesis) (Franzotti et al., 2000).

\section{CONCLUSION}

It can be concluded that studies with new active principles are important for understanding the complex mechanism of inflammation. Academic institutions should invest in this type of study with medicinal plants and thus, contribute to the benefit of the populations needing this type of health care.

\section{ACKNOWLEDGEMENTS}

The authors thank the University of Illinois in Chicago, U.S.A., for the use of the NAPRALERT database for this study. Thanks are also due to Dr. Jnanabrata Bhattacharyya for the help in the preparation of this manuscript.

\section{REFERENCES}

Alexandre-Moreira MS, Piuvezam MR, Araujo CC, Thomas $\mathrm{G}$ 1999. Studies on the anti-inflammatory and analgesic activity of Curatella americana L. $J$ Ethnopharmacol 67: 171-177.

Almeida RN, Barbosa-Filho JM, Naik SR 1985. Chemistry and pharmacology of an ethanol extract of Bumelia sartorum. J Ethnopharmacol 14: 173-185.

Almeida FRC, Rao VSN, Matos MEO 1992. Anti-inflammatory, antitumour and antifertility effects in rodents of two nor-cucurbitacin glucosides from Wilbrandia species. Phytother Res 6: 189-193.

Almeida RN, Navarro DS, Barbosa-Filho JM 2001. Plants with 


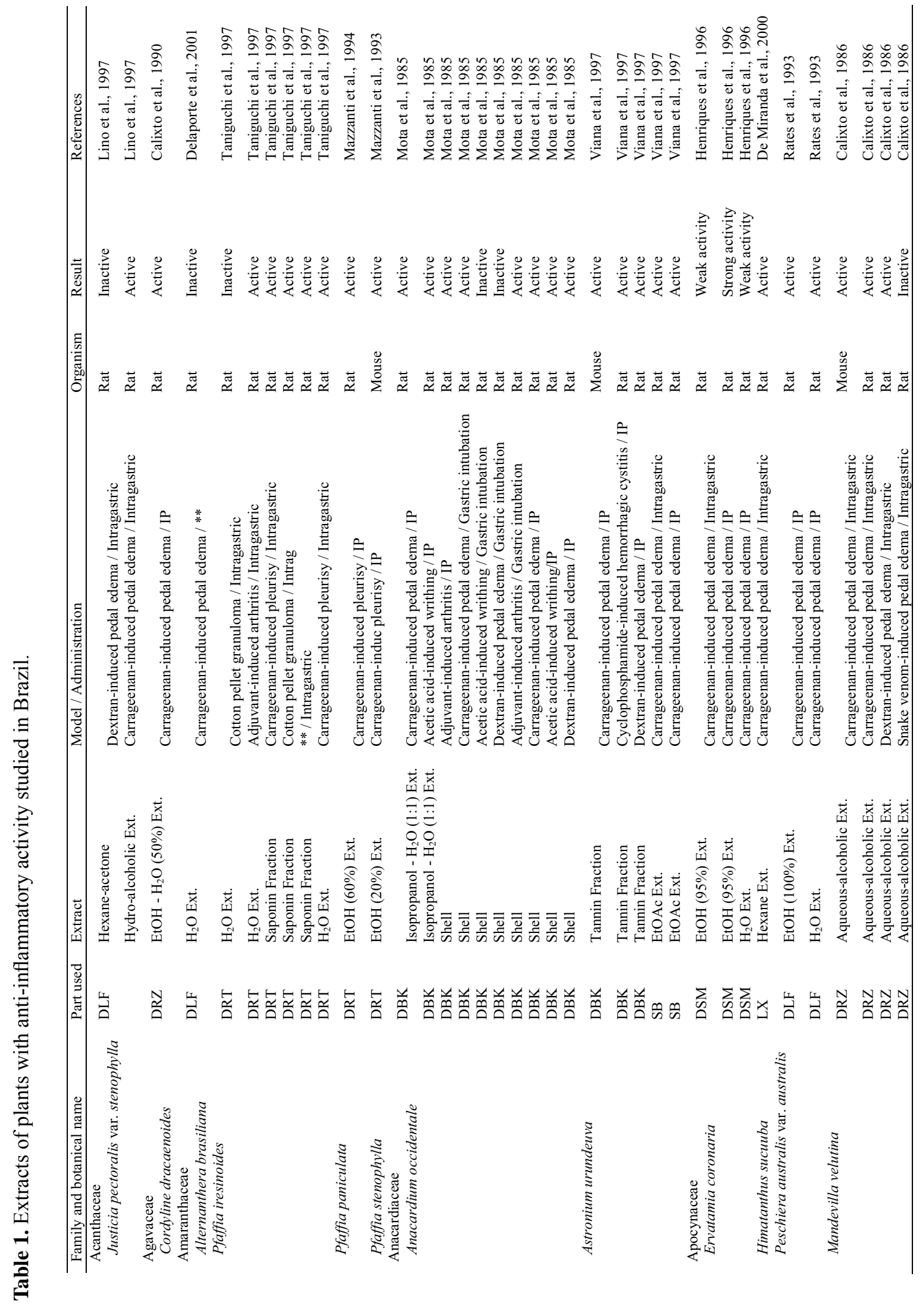




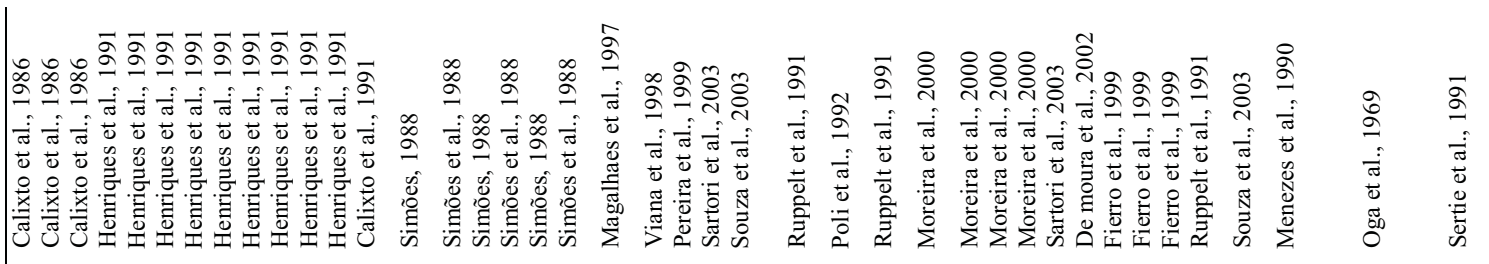

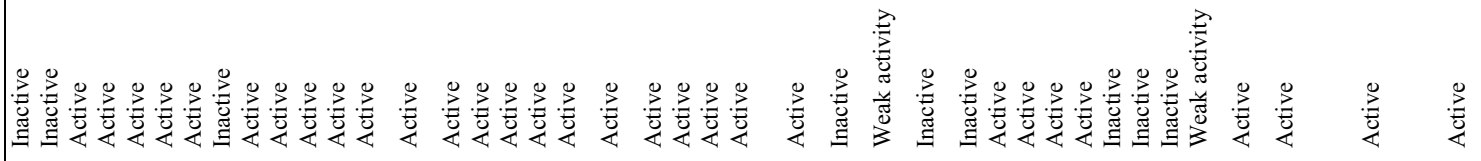

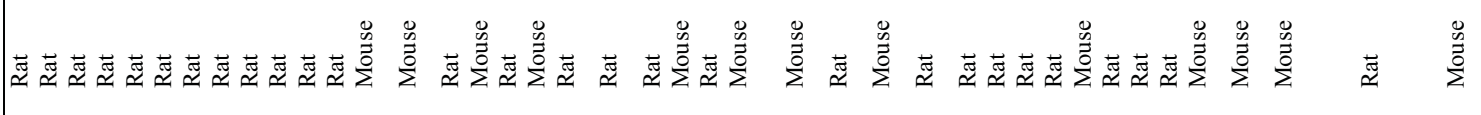
吾

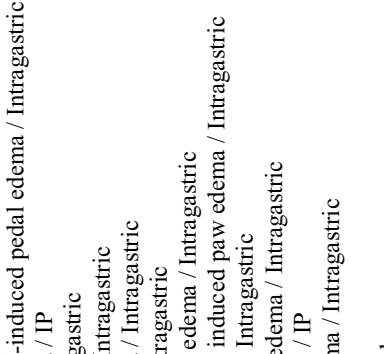

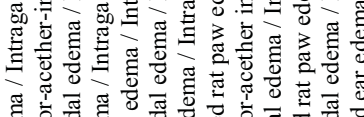

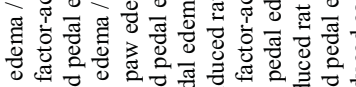

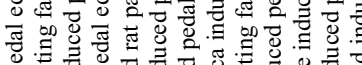

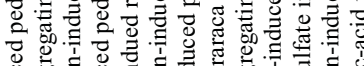

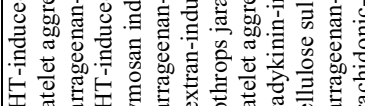

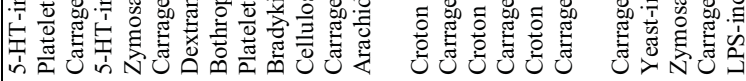

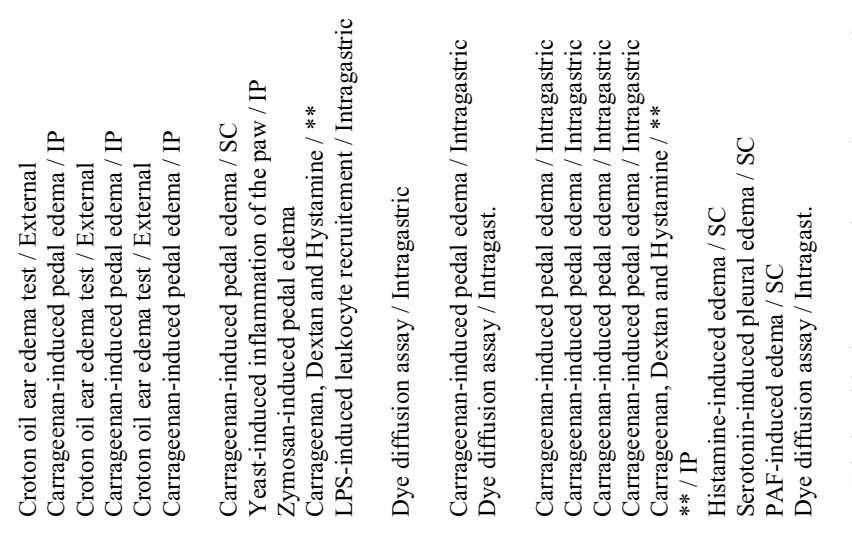

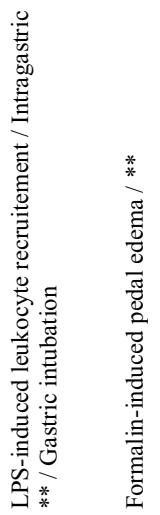

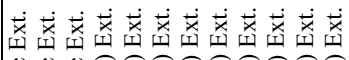

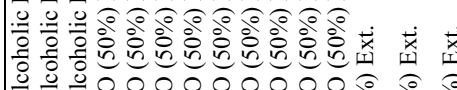

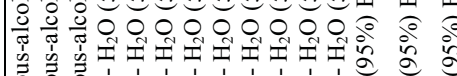

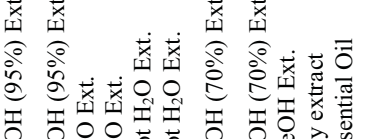

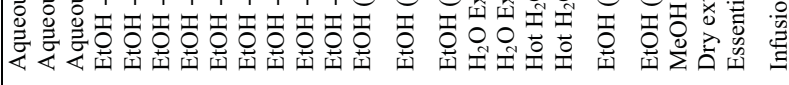

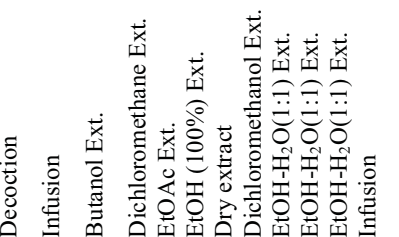

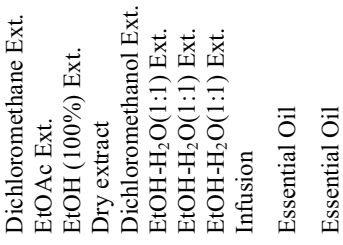

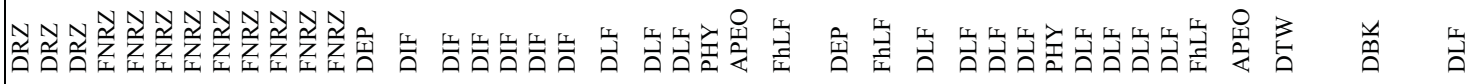
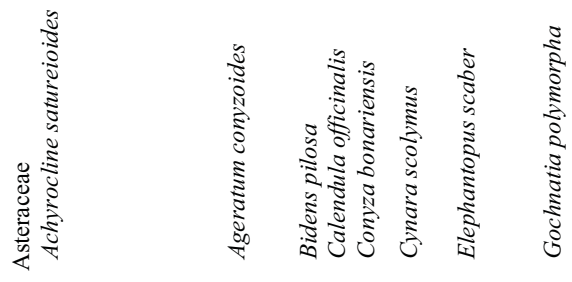

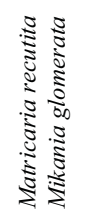

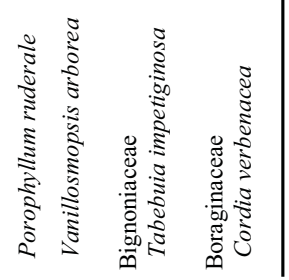




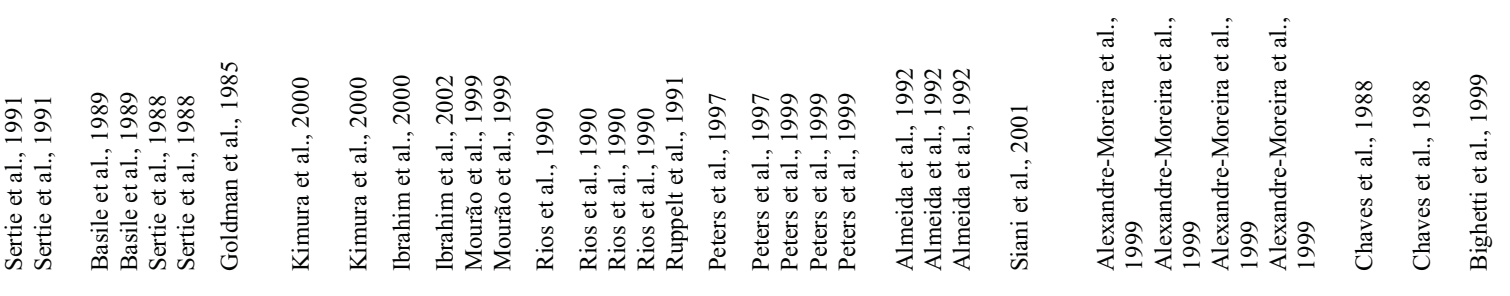

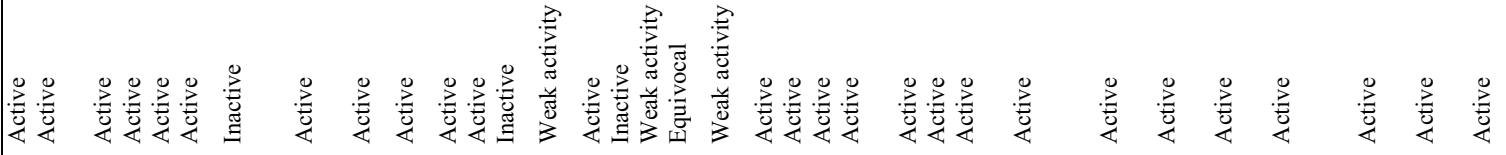

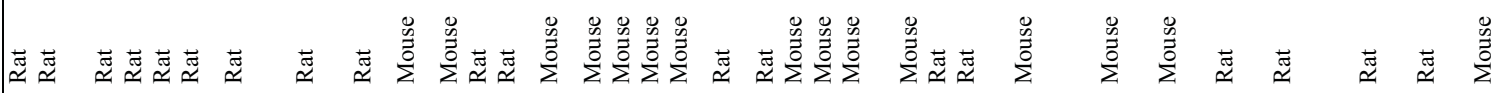

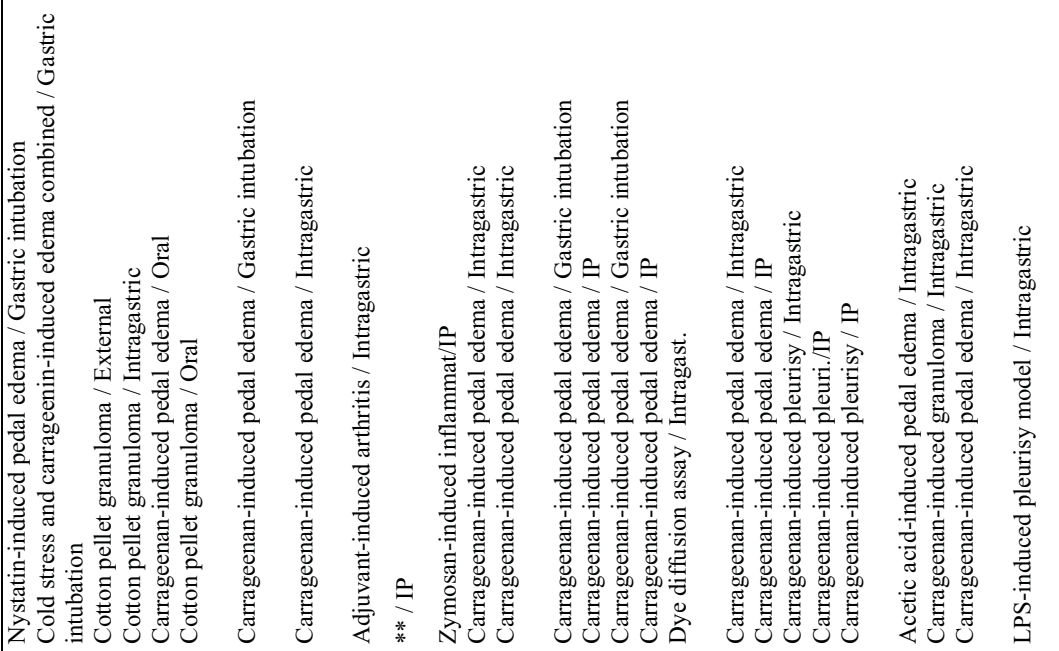

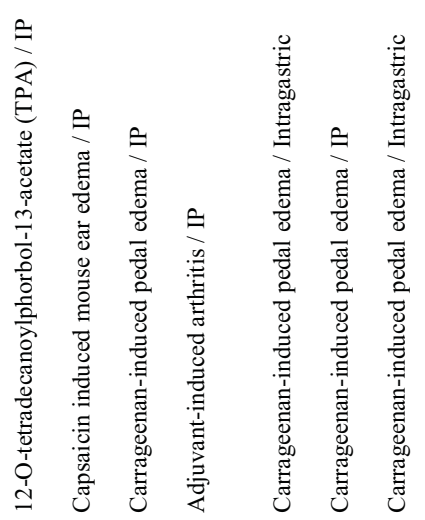

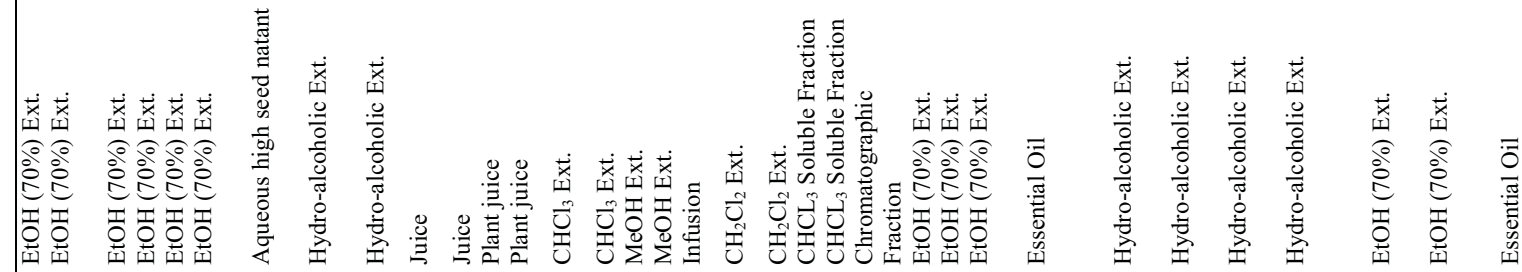

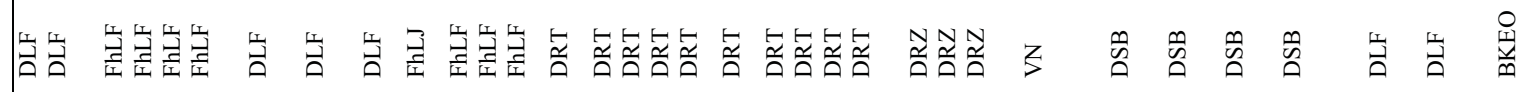
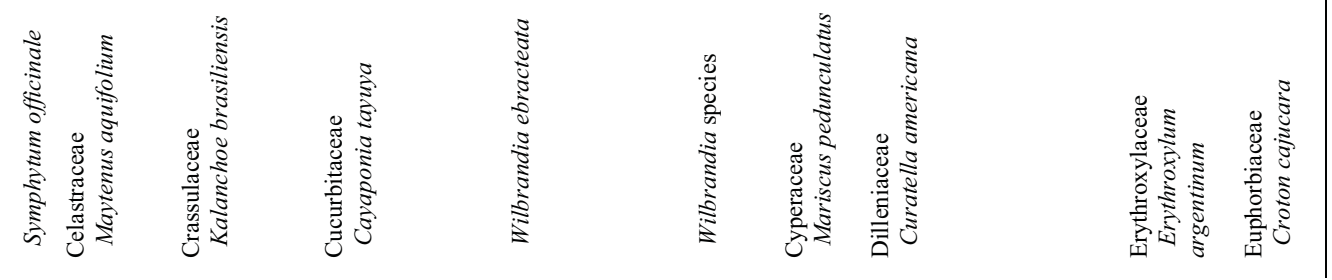


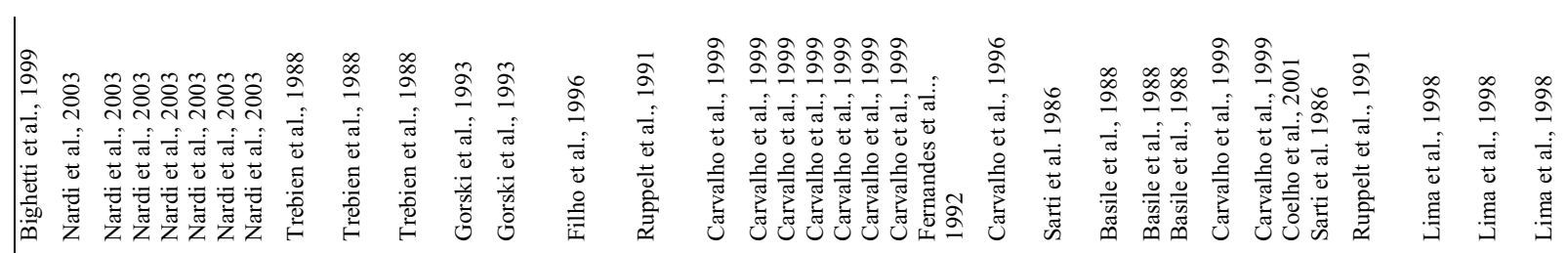

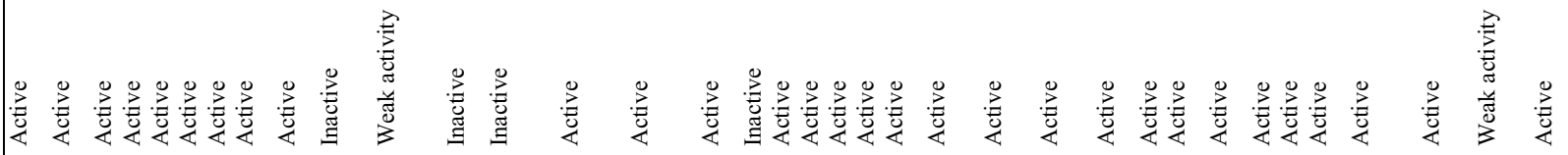

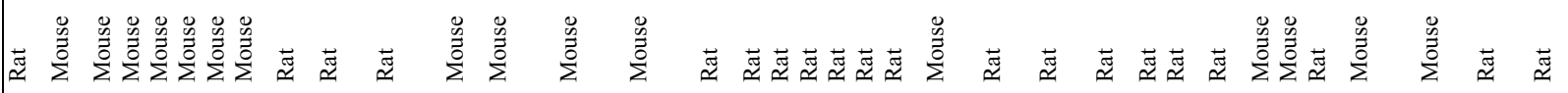

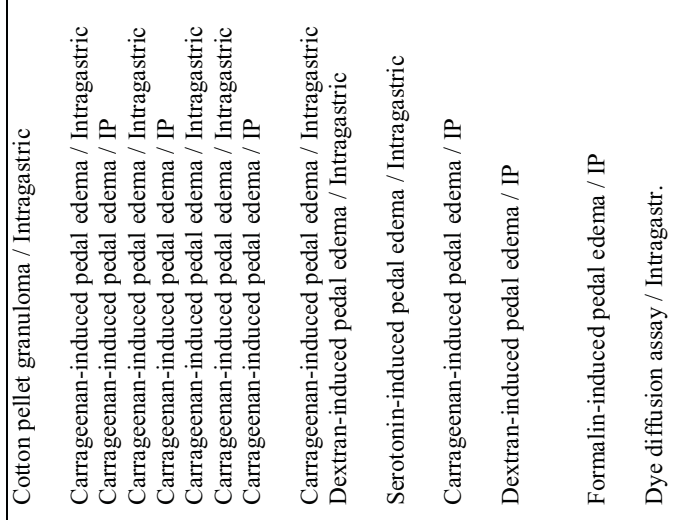

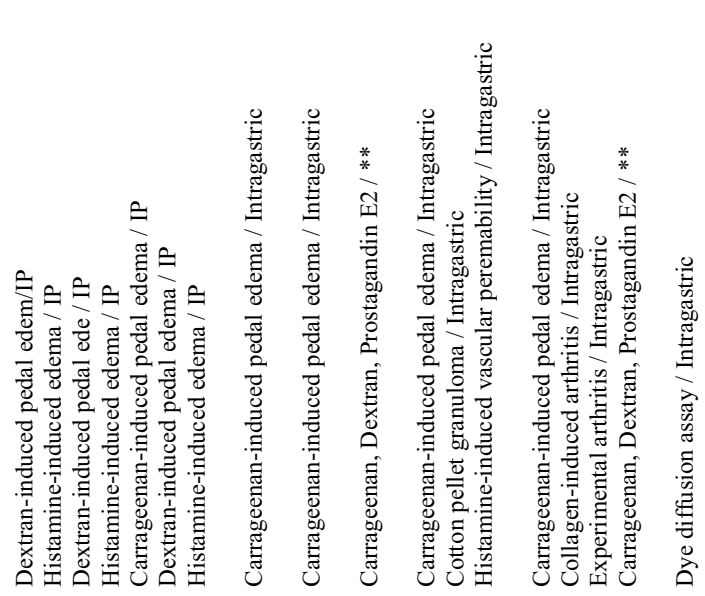

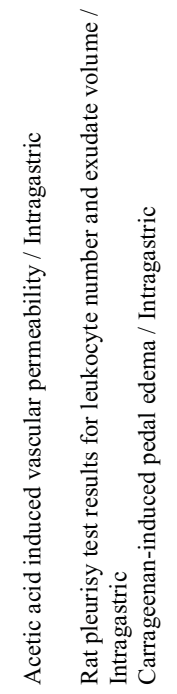

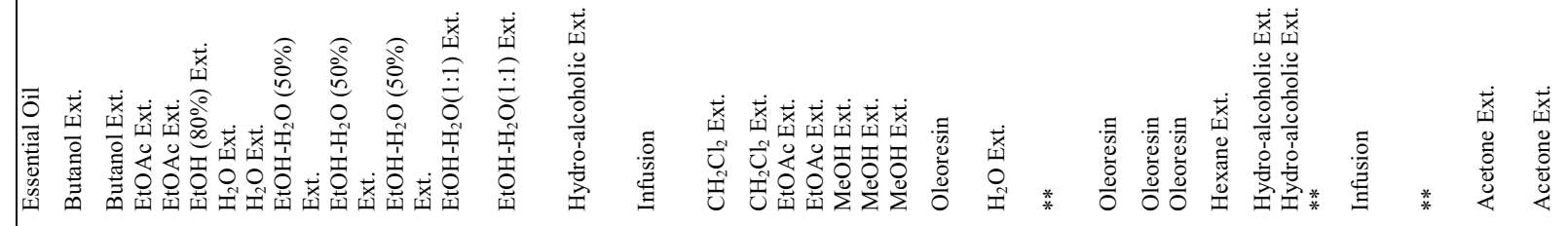

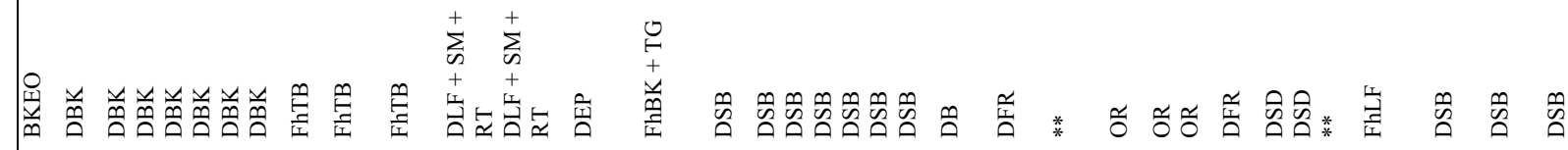
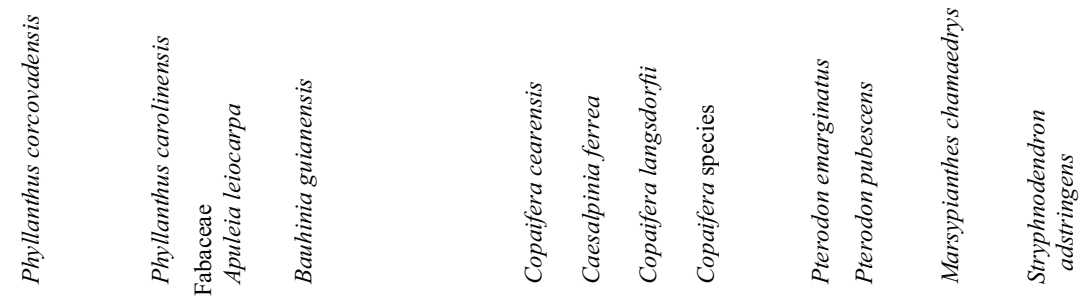


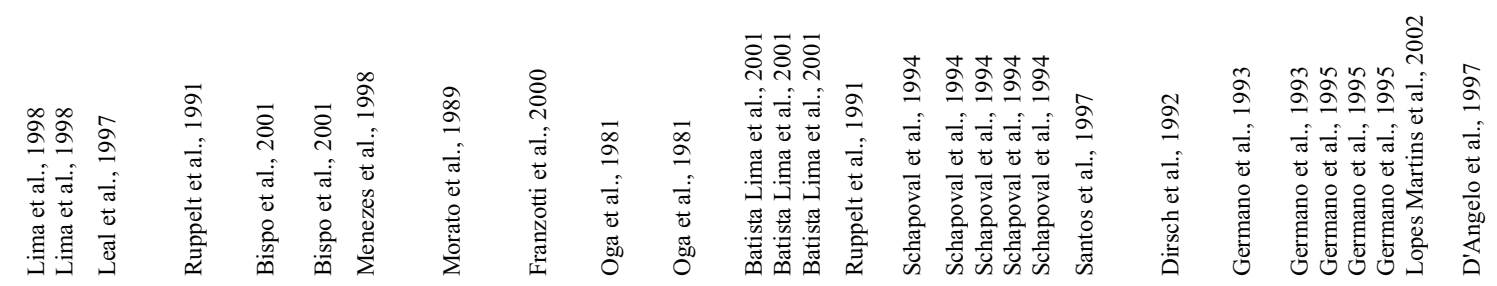

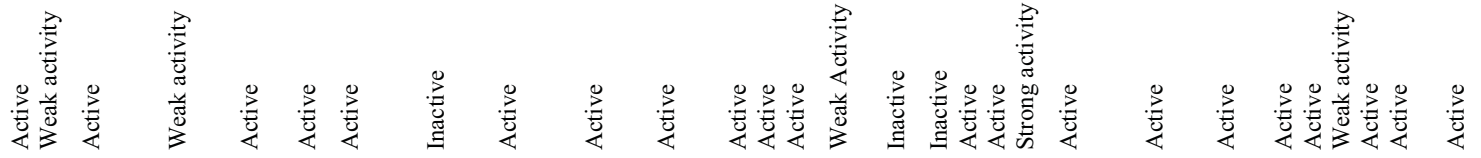

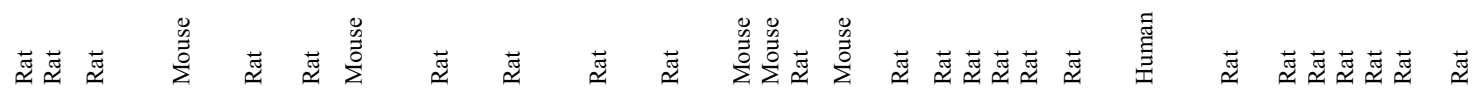

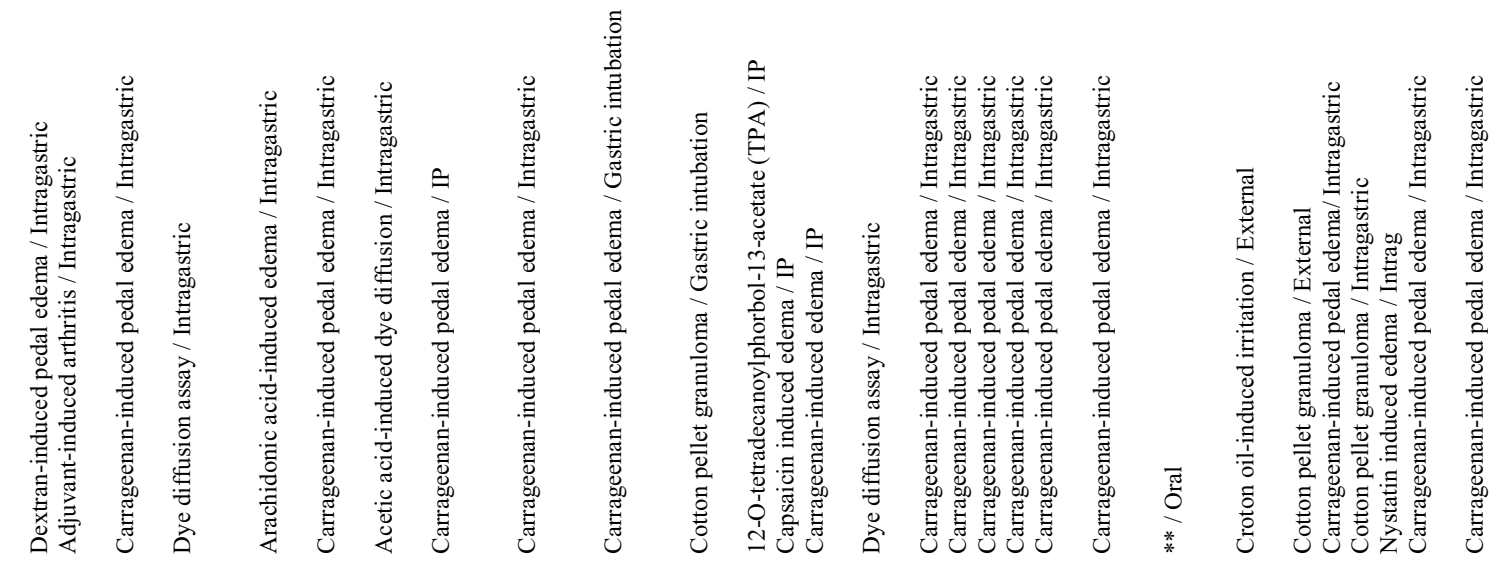

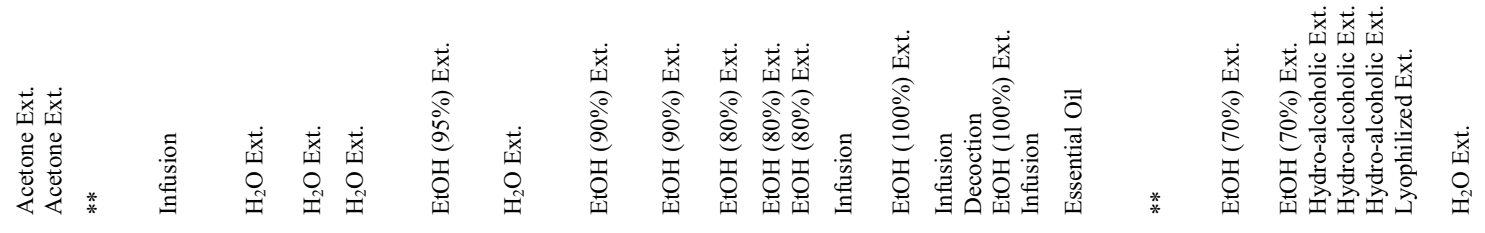

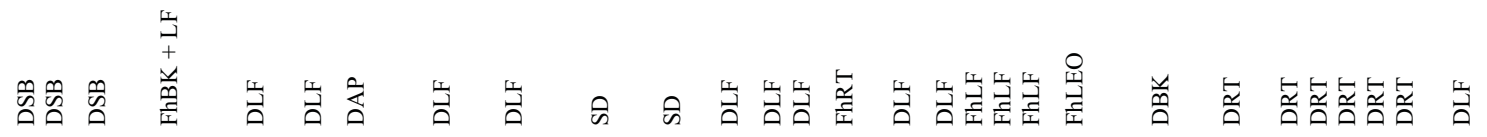

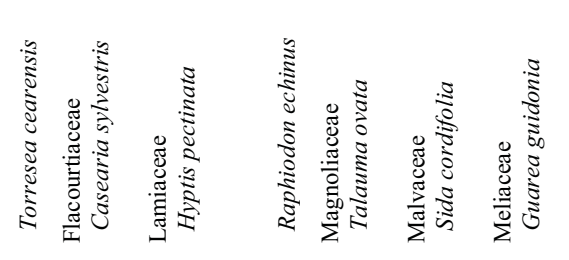
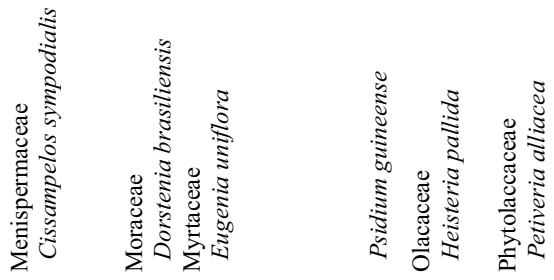


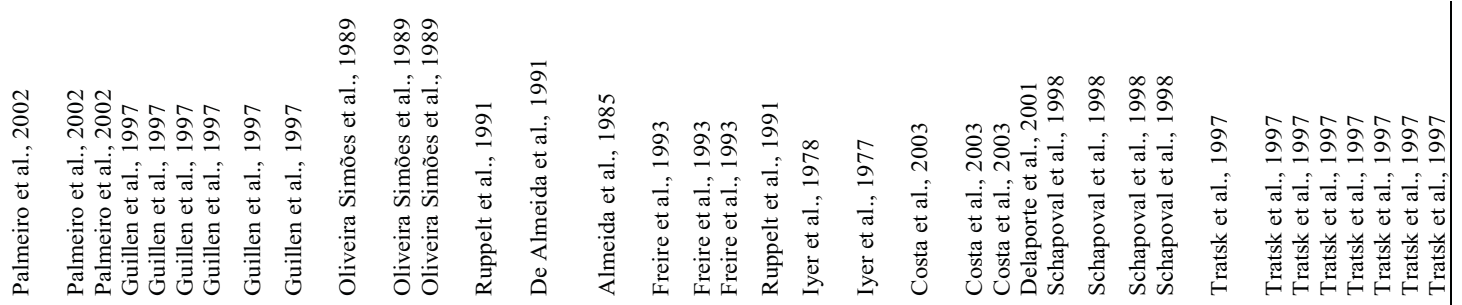

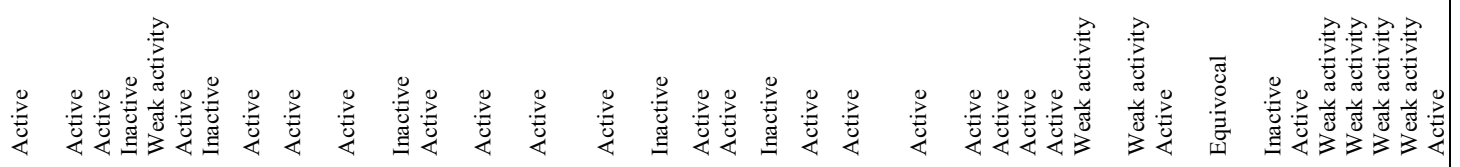

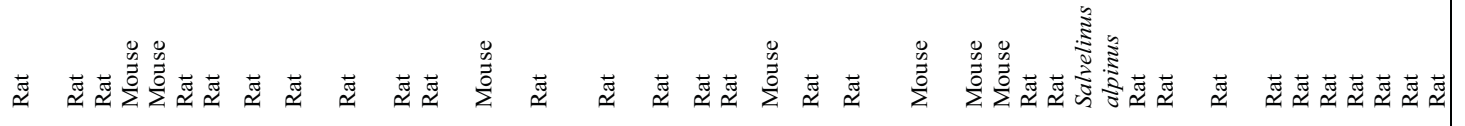

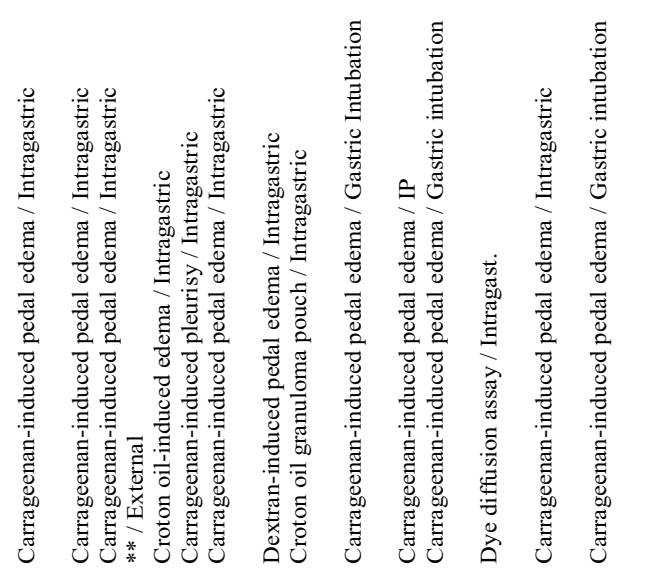

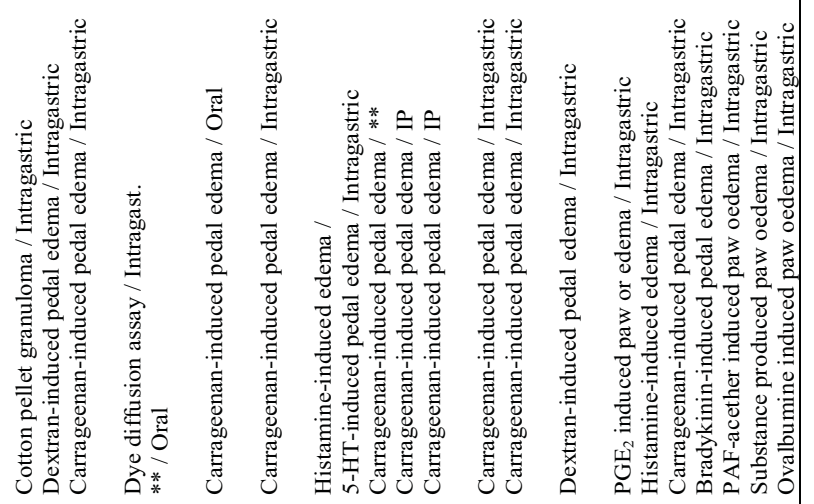

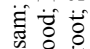

穿

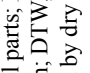

हु

可 흘

话苍

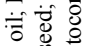

要

产

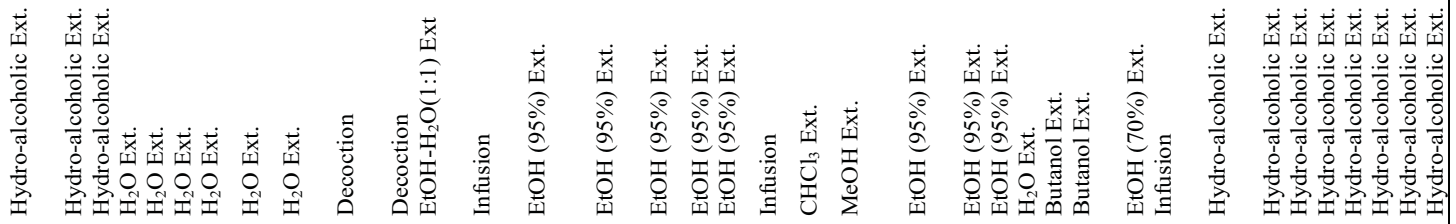

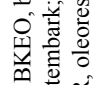

क्षे

焉

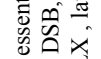

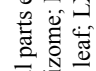

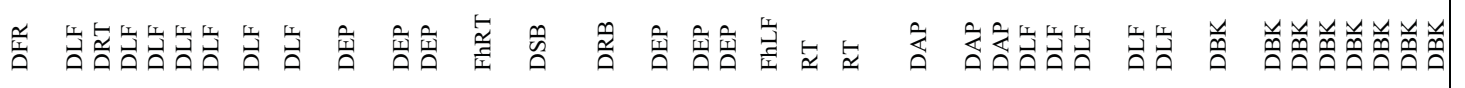

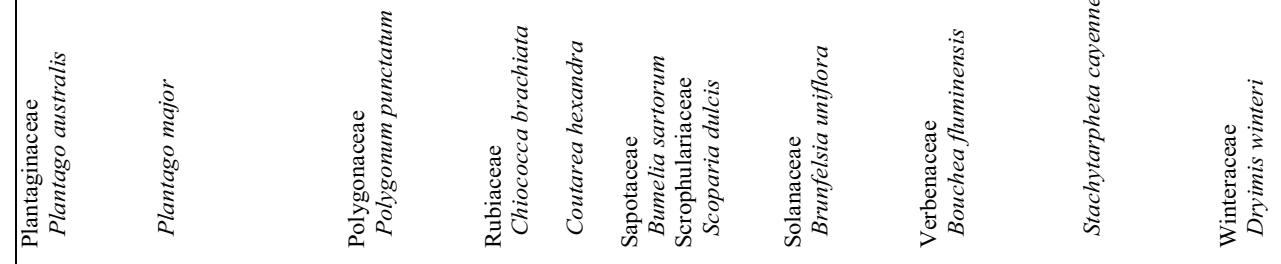


central analgesic activity. Phytomedicine 8: 310322.

Basile AC, Sertie JAA, Freitas PCD, Zanini AC 1988. Antiinflammatory activity of oleoresin from Brazilian Copaifera. J Ethnopharmacol 22: 101-109.

Basile AC, Sertie JAA, Oshiro T, Caly KDV, Panizza S 1989. Topical anti-inflammatory activity and toxicity of Cordia verbenacea. Fitoterapia 60: 260-263.

Batista Lima KV, Ribeiro R, Balestieri FMP, Thomas G, Piuvezam MR 2001. Anti-inflammatory activity of Cissampleos sympodialis Eichl. (Menispermaceae) leaf extract. Acta Farm Bonaerense 20: 275-279.

Bighetti EJB, Hiruma-Lima CA, Gracioso JS, Brito ARMS 1999. Anti-inflamamtory and antinociceptive effects in rodents of the essential oil of Croton cajucara Benth. J Pharm Pharmacol 51: 1447-1453.

Bispo MD, Mourão RHV, Franzotti EM, Bomfim KBR, Arrigoni Blank MDF, Moreno MPN, Marchioro M, Antoniolli AR 2001. Antinociceptive and antiedematogenic effects of the aqueous extract of Hyptis pectinata leaves in experimental animals. $J$ Ethnopharmacol 76: 81-86.

Calixto JB, Nicolau M, Trebien H, Henrique MGO, Weg VB, Cordeiro RSB, Yunes RA 1986. Antiedematogenic actions of a hydroalcoholic crude water-alcohol extract of Mandevilla velutina. Braz J Med Biol Res 19: 4-5.

Calixto JB, De Lima TCM, Morato GS, Nicolau M, Takahashi RN, Valle RMR, Schmidt CC, Yunes RA 1990. Chemical and pharmacological analysis of the crude aqueous/alcoholic extract from Cordyline dracaenoides. Phytother Res 4: 167-171.

Calixto JB, Zanini JC, Cruz AB, Yunes RA, Medeiros YS 1991. Extract and compounds obtained from Mandevilla velutina inhibit arachidonic acid-induced ear or edema in mice, but not rat stomach contraction. Prostaglandins 41: 515-526.

Carvalho JCT, Teixeira JRM, Souza PJC, Bastos JK, Filho DDS, Sarti SJ 1996. Preliminary studies of analgesic and anti-inflammatory properties of Caesalpinia ferrea crude extract. J Ethnopharmacol 53: 175-178.

Carvalho JCT, Santos LS, Viana EP, De Almeide SSMS, Marconato E, Rodrigues M, Ferreira LR, Van De Kamp A 1999. Anti-inflammatory and analgesic activities of the crude extracts from stem bark on Bauhinia guianensis. Pharm Biol 37: 281-284.

Carvalho JCT, Sertie JAA, Barbosa MVJ, Patricio KCM, Caputo LRG, Sarti SJ, Ferreira LP, Bastos JK 1999. Anti-inflammatory activity of the crude extract from the fruits of Pterodon emarginatus Vog. $J$ Ethnopharmacol 64: 127-133.

Chaves CG, Schapoval EES, Zuanazzi JA, Diehl E, Se Siqueira NCS, Henriques AT 1988. Erythroxylum argentinum: assays for anti-inflammatory activity. $J$ Ethnopharmacol 22: 117-120.

Coelho MGP, Marques PR, Gayer CR, Vaz LCA, Neto JFNN, Carvalho Sabino KC 2001. Subacute toxicity evaluation of a hydroalcoholic extract of Pterodon pubescens seeds in mice with collagen-induced arthritis. J Ethnopharmacol 77: 159-164.

Costa VB, Coube CS, Marinho BG, Matheus ME, Leitão SG, Fernandes PD 2003. Anti-inflammatory and analgesic activity of Bouchea fluminensis.
Fitoterapia 74 : 364-371.

Dassoler M, Schwanz M, Busseto F, Moreira EA, Gutierrez L 2004. Perfil fitoquímico e ensaio farmacológico de Averrhoa carambola L. (Oxalidaceae). Jornal Brasileiro de Fitomedicina 2: 4-8.

D'Angelo LCA, Zavier HS, Torres LMB, Lapa AJ, Souccar C 1997. Pharmacology of Piper marginatum Jacq. a folk medicinal plant used as an analgesic, antiinflammatory and hemostatic. Phytomedicine 4: 33-40.

De Almeida ER, De Santana CF, De Mello JF 1991. Antiinflammatory activity of Coutarea hexandra. Fitoterapia 62: 447-448.

De Miranda AL, Silva JR, Rezende CM, Neves JS, Parrini SC, Pinheiro MLB, Cordeiro MC, Tamgborini E, Pinto AC 2000. Anti-inflammatory and analgesic activities of the latex containing triterpenes from Himatanthus sucuuba. Planta Med 66: 284-286.

De Moura RS, Costa SS, Jansen J, Silva CA, Lopes CS, Bernardo-Filho M, Da Silva VN, Criddle DN, Portela N, Rubenich LMS, Araujo RG, Carvalho LCRM 2002. Bronchodilator activity of Mikania glomerata Sprengel on human bronchi and guineapig trachea. J Pharm Pharmacol 54: 249-256.

Delaporte RH, Sanchez GM, Cuellar AC, Demello JCP 2001. Quality control and anti-inflammatory activity of the plant drugs Alternanthera brasiliana (L.) Kuntze and Bouchea fluminensis (Vell.) Mold. Acta Farm Bonaerense 20: 39-46.

Dirsch V, Wiemann W, Wagner H 1992. Anti-inflammatory activity of triterpene quinone-methides and proanthocyanidins from the stem bark of Heisteria pallida Engl. Pharm Pharmacol Lett 2: 184-186.

Fernandes RM, Pereira NA, Paulo LG 1992. Anti-inflammatory activity of copaiba balsam (Copaifera cearensis, Huber). Rev Brasil Farm 73: 53-56.

Fierro IM, Da Silva ACB, Da Silva Lopes C, De Moura RS, Barja-Fidalgo C 1999. Studies on the anti-allergic activity of Mikania glomerata. J Ethnopharmacol 66: 19-24.

Filho VC, Santos ARS, De Campos ROP, Migueo OG, Yunes RA, Ferrari F, Messna I, Calixto JB 1996. Chemical and pharmacological studies of Phyllanthus caroliniensis in mice. J Pharm Pharmacol 48: 1231-1236.

Franzotti EM, Santos CVF, Rodrigues HMSL, Mourão RHV, Andrade MR, Antoniolli AR 2000. Antiinflammatory, analgesic activity and acute toxicity of Sida cordifolia L. (malva-branca). J Ethnopharmacol 72: 273-278.

Freire SMDF, Emim JADS, Torres LMB 1993. Analgesic and anti-inflammatory properties of Scoparia dulcis L. extracts and glutinol in rodents. Phytother Res 7: 408-414.

Gaddi A, Cícero AFG, Pedro EJ 2004. Clinical perspectives of anti-inflammatory therapy in the elderly: the lipoxigenase (LOX)/cycloxigenase (COX) inhibition concept. Arch Gerontol Geriatr 38: 201212.

Germano DHP, Caldeira TTO, Mazella AAG, Sertie JAA, Bacchi EM 1993. Topical anti-inflammatory activity and toxicity of Petiveria alliaceae. Fitoterapia 64: 459-467. 
Germano DHP, Sertie JAA, Bacchi EM 1995. Pharmacological assay of Petiveria alliacea L.: oral anti-inflammatory activity and gastrotoxicity of a hydroalcoholic root extract. Fitoterapia 66: 195-202.

Goldman RS, Freitas PCD, Oga S 1985. Wound healing and analgesic effect of crude extracts of Symphytum officinale rats. Fitoterapia 56: 323-329.

Gonçalves MCR, Moura LSA, Rabelo AL, Barbosa-Filho JM, Cruz HMM, Cruz J 2000. Produtos naturais inibidores da enzima HMG CoA redutase. Rev Bras Farm 81: 89-99.

Gorski F, Correa CR, Filho VC, Yunes RA, Calixto JB 1993. Potent antinociceptive activity of a hydroalcoholic extract of Phyllanthus corcovadensis. J Pharm Pharmacol 45: 1046-1049.

Guillen MEN, Emim JAS, Souccar C, Lapa AJ 1997. Analgesic and anti-inflammatory activities of the aqueous extract of Plantago major L. Int J Pharmacogn 35: 99-104.

Henriques AT, Melo AA, Moreno PRH, Ene LL, Henriques JAP, Schapoval EES 1996. Ervatamia coronaria: chemical constituents and some pharmacological activities. J Ethnopharmacol 50: 19-25.

Henriques MGMO, Fernandes PD, Weg VB, Yunes RA, Cordeiro RSB, Calixto JB 1991. Inhibition of rat paw or edema and pleurisy by the extract from Mandevilla velutina. Agents Actions 33: 272-278.

Ibrahim T, Pereira RLC, Almeida AP, Madi K, Fonseca LBM, Costa SS, Gonçalves Moraes VL 2000. Antiinflammatory effect of Kalanchoe brasiliensis on zymosan-induced arthritis in mice. Phytomedicine Suppl 7: 110.

Ibrahim T, Cunha JMT, Madi K, Da Fonseca LMB, Costa SS, Koatz VLG 2002. Immunomodulatory and antiinflammatory effects of Kalachoe brasiliensis. Int Immunopharmacol 2: 875-883.

Iyer RP, Brown JK, Chaubal MG, Malone MH 1977. Brunfelsia hopeana I.: hippocratic screening and antiinflammatory evaluation. Lloydia 40: 356-360.

Iyer RP, Chaubal MG 1978. Brunfelsia hopeana pharmacologic screening: isolation and characterization of hoppeanine. Diss Abstr Int B 39: 761.

Kimura E, Albiero ALM, Cuman RKN, Caparroz-Assef SM, Oga S, Bersani-Amado CA2000. Effect of Maytenus aquifolium extract on the pharmacokinetic and antiinflammatory effectivenes of piroxicam in rats. Phytomedicine 7: 117-121.

Leal LKAM, Matos ME, Matos FJA, Ribeiro RA, Ferreira FV, Viana GSB 1997. Antinociceptive and antiedematogenic effects of the hydroalcoholic extract and coumarin from Torresea cearensis Fr. All. Phytomedicine 4: 221-227.

Lima JCS, Martins DTO, De Souza Jr PT 1998. Experimental evaluation of stem bark of Stryphnodendron adstringens (Mart.) Coville for anti-inflammatory activity. Phytother Res 12: 218-220.

Lino CS, Taveira ML, Viana GSB, Matos FJA 1997. Analgesic and antiinflammatory activities of Justicia pectoralis Jacq and its main constituents: coumarin and umbelliferone. Phytother Res 11: 211-215.

Lopes Martins RAB, Pegoraro DH, Woisky R, Penna SC, Sertie JAA 2002. The anti-inflammatory and analgesic effects of a crude extract of Petiveria alliacea $\mathrm{L}$.
(Phytolaccaceae). Phytomedicine 9: 245-248.

Lope ER, Chapadeiro E, Raso P, Tafuri WL 1987. Bogliolo - Patologia. 4. ed. Belo Horizonte: Guanabara Koogan, p.67-112.

Magalhães JFG, Viana CFG, Aragão Junior AGM, Moraes VG, Ribeiro RA, Vale MR 1997. Analgesic and antiinflammatory activities of Ageratum conyzoides in rats. Phytother Res 11: 183-188.

Mazzanti G, Braghiroli L, Tita B, Bolle P, Piccinelli D 1993. Anti-inflammatory activity of Pfaffia paniculata (Marticus) Kuntze and Pfaffia stenophylla (Sprengel) Stuchl. Pharmacol Res 27: 91-92.

Mazzanti G, Braghiroli L 1994. Analgesic and anti-inflammatory action of Pfaffia paniculata (Marticus) Kuntze. Phytother Res 8: 413-416.

Menezes AMS, Almeida FRC, Rao VSN, Matos MEO 1990. Anti-inflammatory activity of the essential oil of Vanillosmopsis arborea. Fitoterapia 61: 252-254.

Menezes FS, Cardoso GLC, Pereira NA, Borsatto AS, Kaplan MAC 1998. Phytochemical and pharmacological studies on Raphiodon echinus. Fitoterapia 69: 459460.

Morais LCSL, Barbosa-Filho JM, Almeida RN 2003. Plants and bioactives compounds for the treatment of Parkinson's desease. Arquivo de Fitomedicina 1: 127-132.

Morato GS, Calixto JB, Cordeiro L, De Lima TCM, Morato EF, Nicolau M, Rae GA, Takahashi RN, Valle RMR, Yunes RA 1989. Chemical and pharmacological studies on Talauma ovata ST. Hil. (Magnoliaceae). J Ethnopharmacol 26: 277-286.

Moreira AS, Spitzer V, Schapoval EES, Schnekel EP 2000. Antiinflammatory activity of extracts and fractions from the leaves of Gochnatia polymorpha. Phytother Res 14: 638-640.

Mota MLR, Thomas G, Barbosa Filho JM 1985. Antiinflammatory actions of tannins isolated from the bark of Anacardium occidentale L. $J$ Ethnopharmacol 13: 289-300.

Moura MD, Torres AR, Oliveira RAG, Diniz MFFM, BarbosaFilho JM 2001. Natural products as inhibitors of models of mammary neoplasia. The British Journal of Phytoterapy 5:124-145.

Moura MD, Silva JSE, Oliveira RAG, Diniz MFFM, BarbosaFilho, JM 2002. Natural products reported as potencial inibitors of uterine cervical neoplasia. Acta Farm Bonaerense 21: 1-7.

Mourão RHV, Santos FO, Franzotti EM, Moreno MPN, Antoniolli AR 1999. Anti-inflammatory activity and acute toxicity (LD50) of the juice of Kalanchoe brasiliensis (Comb.) leaves picked before and during blooming. Phytother Res 13: 352-354.

Nardi GM, Felippi R, Dalbo S, Siqueira-Junior JM, Arruda DC, Monache FD, Timbola AK, Pizzolatti MG, Ckless K, Ribeiro-do-Valle RM 2003. Anti-inflammatory and antioxidant effects of Croton celtidifolius bark. Phytomedicine 10: 176-184.

Oga S, Sekino T 1969. Toxicity and anti-inflammatory activity of Tabebuia avellanedae extracts. Rev Fac Farm Bioquim Univ Sao Paulo 7: 47-53.

Oga S, Sertie JA, Brasile AC, Hanada S 1981. Anti-inflammatory effect of crude extract from Guarea guidonia. Planta Med 42: 310-312. 
Oliveira Simões CM, Ribeiro-do-Vale RM, Poli A, Nicolau M, Zanin M 1989. Pharmacological investigation on Polygonum punctatum Elliot (Pacre HBK) extracts. Part I: Tests in vivo. J Pharm Belg 44: 275-284.

Palmeiro NMS, Almeida CE, Ghedini PC, Goulart LS, Baldisserotto B 2002. Analgesic and antiinflammatory properties of Plantago australis hydroalcoholic extract. Acta Farm Bonaerense 21: 89-92.

Pereira RLC, Ibrahim T, Lucchetti L, Da Silva AJR, De Moraes VLG 1999. Immunosuppressive and antiinflammatory effects of methanolic extract and the polyacetylene isolated from Bidens pilosa L. Immunopharmacology 43: 31-37.

Pereira JV, Modesto-Filho J, Agra MF, Barbosa-Filho JM 2002. Plant and plant-derived compounds employed in prevention of the osteoporosis. Acta Farm Bonaerense 21: 223-234.

Peters RR, Farias MR, Ribeiro-do-Valle RM 1997. Antiinflammatory and analgesic effects of curcubitacins from Wilbrandia ebracteata. Planta Med 63: 525528.

Peters RR, Saleh TF, Lora M, Patry C, De Brum-Fernandes CAJ, Farisa MR, Ribeiro-do-Valle RM 1999. Anti-inflammatory effects of the products from Wilbrandia ebracteata on carrageenan-induced pleurisy in mice. Life Sci 64: 2429-2437.

Poli A, Nicolau M, Simões CMO, Nicolau RMRDV, Zanin M 1992. Preliminary pharmacologic evaluation of crude whole plant extracts of Elephantopus scaber. Part 1: in vivo studies. J Ethnopharmacol 37: 7176.

Rates SMK, Schapoval EES, Souza IA, Henriques AT 1993. Chemical constituents and pharmacological activities of Peschiera australis. Int J Pharmacogn 31: 288-294.

Rios JL, Giner RM, Jimenez MJ, Wickman G, Hancke JL 1990. A study on the anti-inflammatory activity of Cayaponia tayuya root. Fitoterapia 61: 275-278.

Rocha LG, Almeida JR, Macedo RO, Barbosa-Filho JM. 2005. A review of natural products with antileishmanial activity. Phytomedicine 12: 514-535.

Ruppelt BM, Pereira EFR, Gonçalves LC, Pereira NA 1991. Pharmacological screening of plants recommended by folk medicine as anti-snake venom- 1 . Analgesic and anti-inflammatory activities. Mem I Oswaldo Cruz 86: 203-205.

Sabino KCC, Castro FA, Oliveira JCR, Dalmau SRA, Coelho MGP 1999. Successful treatment of collageninduced arthritis in mice with a hydroalcohol extract of seeds of Pterodon pubescen. Phytother Res 13: 613-615.

Santos FA, Rao VSN, Silveira ER 1997. Anti-inflammatory and analgesic activities of the essential oil of Psidium guianense. Fitoterapia 68: 65-68.

Sarti SJ, Santos Filho D, Souza GEP, Ferreira SH, Leitão Filho HF, Abreu JE, Silva CAA 1986. Atividade antiinflamatória de produtos naturais de origem vegetal. Rev Bras Farmacogn 1(Supl 1): 39-40.

Sartori LR, Ferreira MS, Perazzo FF, Mandalho Lima L, Carvalho JCT 2003. Atividade antiinflamatória do granulado de Calendula officinalis e Matricaria recutita L. Rev Bras Farmacogn 13(Supl 1): 17-19.
Sertie JAA, Basile AC, Panizza S, Matida AK, Zelnik R 1988. Pharmacological assay of Cordia verbenacea: part I. anti-inflammatory activity and toxicity of the crude extract of the leaves. Planta Med 54: 7-10.

Sertie JAA, Basile AC, Panizza S, Oshiro TT, Azzolini CP, Penna SC 1991. Pharmacological assay of Cordia verbenaceae III. oral and topical anti-inflammatory activity and gastrotoxicity of crude leaf extract. $J$ Ethnopharmacol 31: 239-247.

Schapoval EES, Silveira SM, Miranda ML, Alice CB, Henriques AT 1994. Evaluation of some pharmacological activities of Eugenia uniflora L. J Ethnopharmacol 44: 137-142.

Schapoval EES, De Vargas MRW, Chaves CG, Bridi R, Zuanazzi JA 1998. Anti-inflammatory and antinociceptive activities of extracts and isolated compounds from Stachytarpheta cayennensis. J Ethnopharmacol 60: 53-59.

Siani AC, Silva AMP, Nakamura MJ, De Carvalho MV, Henriques MGMO, Ramos MFS, Kaiser CR 2001. Chemical composition and anti-inflammatory activity of the hydrodistillat from Mariscus pedunculatus. J Braz Chem Soc 12: 354-359.

Silva JSE, Moura MD, Oliveira RAG, Diniz MFFM, BarbosaFilho JM 2003. Natural product inibitors of ovarian neoplasia. Phytomedicine 10: 221-232.

Simões CMO 1988. Anti-inflammatory action of Achyrocline satureioides extracts aplied topically. Fitoterapia 59: 419-421.

Simões CMO, Schenkel EP, Bauer L, Langeloh A 1988. Pharmacological investigations on Achyrocline satureioides (Lam). DC, Compositae. J Ethnopharmacol 22: 281-293.

Sosa S, Balick MJ, Arvigo R, Esposito RG, Pizza C, Altinier G, Tubaro A 2002. Screening of the topical antiinflammatory activity of some Central American plants. J Ethnopharmacol 81: 211-215.

Souza MC, Siani AC, Ramos MFS, Menezes de Lima O, Henriques MGMO 2003. Evaluation of antiinflammatory activity of essential oils from two Asteraceae species. Pharmazie 58: 582-586.

Taniguchi SF, Bersani-Amado C, Sudo LS, Assef SMC, Oga S 1997. Effect of Pfaffia iresinoides on the experimental inflammatory process in rats. Phytother Res 11: 568-571.

Tratsk KS, Campos MM, Vaz ZR, Filho VC, Schlemper V, Yunes RA, Calixto JB 1997. Anti-allergic effects and edema inhibition caused by the extract of Drymis winteri. Inflamm Res 46: 509-514.

Trebien HA, Neves PCA, Yunes RA, Calixto JB 1988. Evaluation of pharmacological activity of a crude hydroalcoholic extract from Jatropha elliptica. Phytother Res 2: 115-118.

Viana CFG, Aragão Jr AGM, Ribeiro RA, Magalhães JFG, Vale MR 1998. Effects of Ageratum conyzoides in nociception and inflammatory response induced by zymosan. Fitoterapia 69: 349-354.

Viana GSB, Bandeira MAM, Moura LC, Souza-Filho MVP, Matos FJA, Ribeiro RA 1997. Analgesic and antiinflammatory effects of the tannin fraction from Myracrodruon urundeuva Fr All. Phytother Res 11: 118-122. 